Article

\title{
Regional Mapping of Groundwater Resources in Data-Scarce Regions: The Case of Laos
}

\author{
Mathieu Viossanges* (D), Paul Pavelic, Lisa-Maria Rebelo, Guillaume Lacombe (D) and \\ Touleelor Sotoukee \\ International Water Management Institute-South East Asia Regional Office, Vientiane, Laos; \\ p.pavelic@cgiar.org (P.P.); 1.rebelo@cgiar.org (L.-M.R.); g.lacombe@cgiar.org (G.L.); toulee-lor@hotmail.com (T.S.) \\ * Correspondence: m.viossanges@outlook.com; Tel.: +856-2055750264
}

Received: 22 November 2017; Accepted: 22 December 2017; Published: 23 December 2017

\begin{abstract}
This study focuses on Laos, a landlocked nation located in South-East Asia with sub-tropical climate and highly seasonal rainfall distribution. Laos is one of the world's least developed countries, and currently witnesses an unprecedented level of development that is highly reliant on its natural resources, including groundwater. There is currently very limited data and no nationwide assessment of shallow $(<30 \mathrm{~m})$ groundwater resources to support sustainable management. This study provides a first step towards addressing this issue by (i) identifying the major aquifer units of the country; (ii) integrating localized data and regional maps into an assessment of the groundwater potential; and (iii) producing quantitative maps of key hydrogeological indicators. Eight aquifer units have been described and evaluated: (i) Basement aquifers, (ii) Volcanic aquifers, (iii) Schists, (iv) Paleozoic sedimentary, (v) Karsts, (vi) Limestones, (vii) Mesozoic sedimentary and (viii) Alluvial sediments. The Mesozoic sandstones and the Alluvial aquifers are the most extensive and productive hydrogeological systems in the country. The Volcanic and Karstic aquifers, although poorly known, might also have important potential. This assessment, along with the maps of quantitative aquifer indicators, provide a significant improvement in both spatial resolution and accuracy compared to previously available information. It will likely support improved management plans and the identification of areas with higher potential for groundwater development.
\end{abstract}

Keywords: hydrogeology; Laos; Mekong basin; groundwater mapping; groundwater development potential

\section{Introduction}

Situated in the tropics, Laos is a land-locked country classified by the United Nations Development Program (UNDP) as one of the world's least developed countries (LDCs) with a poverty rate of $23 \%$. As population increases and steady economic growth is leading the country towards exiting the LDCs by 2020 [1], the demand on water resources to meet hydropower, agricultural, industrial, and domestic needs is rising.

Often considered as "water-rich", Laos has a long-term average annual rainfall above $1500 \mathrm{~mm}$. Due to this wealth in rainfall, most attention has been given to surface water systems, in some cases, for irrigation and mainly for electricity production, with major rivers witnessing unprecedented hydropower development [2,3]. Nevertheless, an important constraint of surface water in Laos is its high seasonality in availability, with $80 \%$ of precipitation occurring during the six-month wet season from May to October.

Groundwater, in contrast, was historically not placed under high pressure, and was, until recent years, overlooked in water resource policies and institutionally $[4,5]$. However, interest in the resource is currently growing. Groundwater is often available year-round, and coupled with 
ever-more affordable technologies, imported from neighboring countries, and it is in consequence, increasingly relied upon by Lao communities. The resource is accessed through shallow wells and boreholes, and increasingly used for both domestic consumption and vegetable gardening in the lowland areas [6-10]. As of 2011, 51\% of villages of the country were relying on this resource for their domestic needs, highlighting its vital importance (Agricultural Census 2011, map available in Appendix A). Even considering this increase in use, it was recently observed that groundwater is still underutilized in the country, with significant scope for expansion in high-value economic sectors, such as irrigation and industry, along with securing domestic needs [7].

Since 2012, several policy, institutional, and legal changes have been implemented, taking into consideration the mounting need to develop and better manage groundwater resources [4]. However, at a time when strategic decisions must be made on groundwater resource management, the lack of knowledge and understanding of the resource, and the lack of reliable hydrogeological maps, have been identified as major issues hindering sustainable groundwater development and effective management [7].

Although hydrogeology maps exist at the wider scale of the Lower Mekong River Basin [11-13], it was highlighted [13] that significantly fewer groundwater studies have been undertaken in Laos than its neighboring countries. At the same time, however, some localized studies within Laos can be found in limited numbers [14-22]. These are mainly drilling reports from aid agencies, and are often focused on provision of drinking water supply rather than groundwater resources assessments. Thus, at the national scale, groundwater resources can be considered as largely unknown territory.

This rising interest in groundwater resources, combined with the demonstrated lack of available scientific evidence to support management, highlights the need to identify the major aquifer units of Laos, their spatial distribution, and their development potential. This paper attempts to address this issue by integrating localized studies and large scale regional maps, to provide a country-scale appraisal of the groundwater potential and associated quantitative hydrogeological maps.

\section{Materials and Methods}

\subsection{Study Area}

Laos is located in mainland South-East Asia and bordered by Thailand, Cambodia, Vietnam, Myanmar, and China (Figure 1). With a population of approximately 7 million and an area of $236,800 \mathrm{~km}^{2}$, it is an agrarian economy with a low population density. Flowing in from China and exiting through Cambodia into Vietnam, the Mekong River, one of the largest rivers of the world, with mean annual discharge of $475 \mathrm{~km}^{3}$, forms the lifeline of the country. Mountains extend over the vast majority of the north of the country, and southwards along the border with Vietnam. The lowlands occupy the central and southern part of the country from the Vientiane Plain, and along the Mekong River, towards Cambodia. Precipitation over the wet season (May-October) ranges from $1300 \mathrm{~mm}$ to $3700 \mathrm{~mm}$. The highest values are found in central and southern Laos mountain ranges, where orographic effects enhance the monsoon precipitation. 


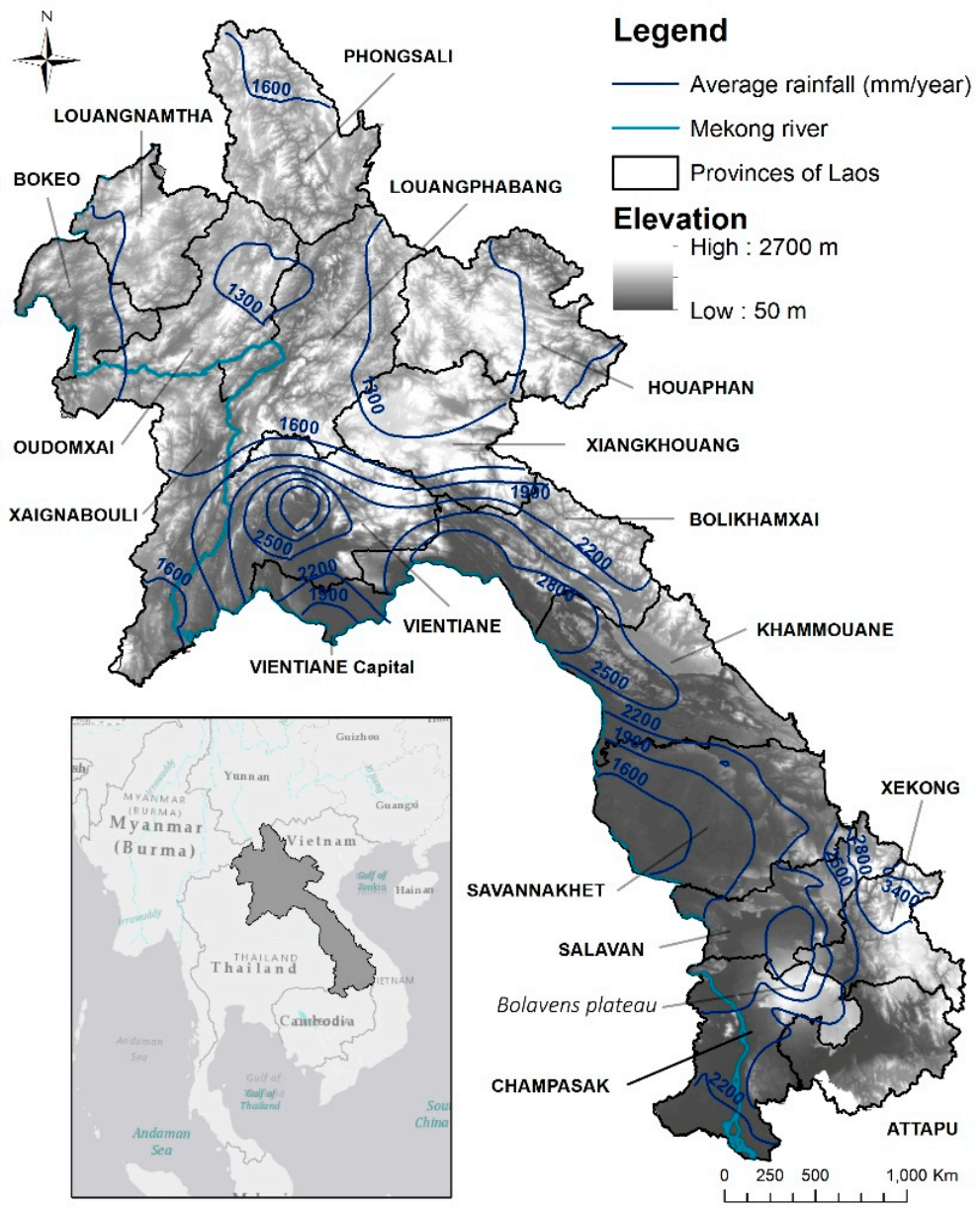

Figure 1. Topography-D.E.M: [23], indicative isohyets of annual average rainfall (CHIRPS data: [24]) and Provinces in Laos.

\subsection{Geological Setting}

Precambrian Basement rocks (>500 Million years (M.y.)) are found scattered in small outcrops in mountains along the Vietnamese border. These are composed of metamorphic rocks such as gneisses and schists, and locally, granite plutons. Subsequent geological history [25] can be summarized as follows: during the Paleozoic (250 to 500 Million years), deep waters that extended in a NW-SE axis along the Vietnamese border resulted in extensive sandstone and mudstone deposits. From the mid-Carboniferous period (320 M.y.), the region witnessed important striking and faulting along both the NW-SE and SW-NE axes that induced the current topography of Laos. Throughout the Paleozoic, sequences of sandstone, siltstone, limestones, and shale were deposited mainly in the Annamite range area and northern Laos. Convergence and tectonic activity was occasionally accompanied by the extrusion of igneous rocks. The Mesozoic era (65 to 250 M.y.) is characterized by important marine deposits, particularly in the south of Laos were shallow lagoon conditions created evaporite layers in some places [26-28]. These Mesozoic sandstones, of a thickness of several hundred meters, constitute the Khorat Plateau found in Thailand that extends into Laos within lowland parts of Vientiane Capital, Vientiane, Savannakhet, and Champassak provinces.

During the Tertiary (2 to 65 M.y.) and Quaternary ( $<2$ M.y.), no large-scale sedimentary process occurred compared to previous eras. Basaltic lava flows, particularly in the south of Laos in Champassak province led to the formation of the Volcanic Bolaven Plateau. On-going tectonics and erosion processes created intra-montane basins that were filled by freshwater Alluvial sediments such as gravels, sands, silts, clays and freshwater sandstones. These Tertiary and Quaternary deposits 
are found notably in the Vientiane Plain and in the south around the Bolaven Plateau, and occasionally along rivers in upland areas.

\subsection{Groundwater Indicators}

In general terms, the groundwater development potential of an aquifer can be characterized in terms of its exploitability, accessibility, and supply reliability $[29,30]$. In this paper, these three components have been expressed as the storage capacity, productivity, and recharge rate of a given aquifer system, respectively.

In order to produce quantitative indicators of the groundwater development potential and associated maps, a specific methodology has been developed, drawing upon insights from similar large-scale studies in data scarce regions (Africa, [31]) and at the global scale [32]. As detailed hereafter, the initial collection of available datasets, reports, and maps allowed major aquifer systems in Laos to be identified, and a database of boreholes to be created. Subsequently maps of the groundwater storage and the aquifer productivity were produced using assumptions of thickness, aquifer properties, and reported yields derived from the database, complemented by global published literature where local data was lacking. The renewability was then discussed using recently published groundwater recharge rates [33]. Each aquifers' groundwater development potential was then described based on these synthetized characteristics (Figure 2).

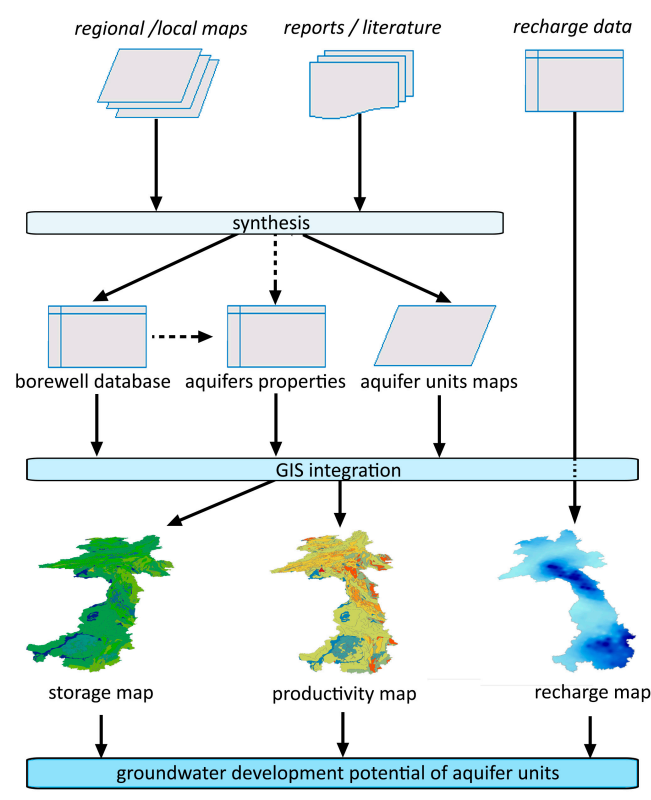

Figure 2. General workflow of the study.

\subsubsection{Aquifer Units Identification and Borewell Database}

The priority in data collection was to obtain the most relevant and up-to-date maps to identify the major aquifer units and their spatial extent. In parallel, a database of wells with associated aquifer properties was constructed for assessing the storage and productivity properties. Reports and maps were obtained from liaising with stakeholders from government agencies, development agencies' archives, and through contact with locally-based NGOs.

\section{Aquifer Identification}

As there are no existing maps of aquifers specific to Laos, the identification of main aquifer units was a prerequisite to assess the groundwater development potential. This identification was carried out using a range of maps at different scales. The hydrogeological groups identified in the Lower Mekong 
River Basin (LMRB) by [11-13] under various programs of the Mekong River Commission (MRC) have been used as an initial classifier. Four major hydrogeological groups were recognized $[12,13]$ and were used to map the resources at a 1:2,000,000 scale over the entire LMRB. However, although these four groups provide a useful initial classifier, this map demonstrated fairly limited accuracy in Laos, mainly due to the large scale of the study and the scarcity of data. The only cited source of data for the Lao component of the map was a geological map of Cambodia-Lao-Vietnam, at a 1:1,000,000 scale published in 1988 in Vietnam [13].

The geological map of Laos published by the Lao Ministry of Mines (MoM), with the support of the Japan International Cooperation Agency (JICA) in 2008, was used in this study to increase accuracy. This 2008 updated 1:1,000,000 scale map [34] was built based on the 1991 geological map produced by the British Geological Survey (BGS) [25]. An important improvement is the integration of several local $1: 200,000$ scale sheets covering approximately $65 \%$ of the country and field visits, providing the most up-to-date spatial information on geology [34].

A hard copy of the map was digitalized to use in a GIS environment. GIS comparison of the updated 2008 geological map of Laos with field data and localized groundwater studies showed that the accuracy of the delineation of geological units have been greatly increased compared to previous maps available [13,25]. Based on the hydrogeological groups (from MRC maps), the updated geological map and other maps of Laos (summarized in Table 1), aquifer units have been identified, described, and mapped for the first time at the specific scale of Laos.

Table 1. Maps used to identify the major aquifer units of Laos (DGVM: Department of Geology and Minerals of Vietnam; BGS: British Geological Survey; MRC: Mekong River Commission. cf. [11-13]; JICA, MEM (DGO, DOM): Japanese International Cooperation Agency; Ministry of Mines (Dept. of Geology, Dept. of Mines).

\begin{tabular}{|c|c|c|c|c|}
\hline Document & Scale & Year & Source & Interest/Limitations \\
\hline $\begin{array}{l}\text { Geological map of } \\
\text { Cambodia-Lao-Vietnam }\end{array}$ & $1: 1,000,000$ & 1988 & DGVM & Early regional map (base for MRC map) \\
\hline $\begin{array}{c}\text { Lao People's } \\
\text { Democratic Republic } \\
\text { (PDR) Geological and } \\
\text { mineral occurrence } \\
\text { map }\end{array}$ & $1: 1,000,000$ & 1991 & BGS & $\begin{array}{l}\text { Includes geological history and detailed } \\
\text { stratigraphy relevant for hydrogeology. } \\
\text { Accuracy is limited compared to } \\
\text { regional maps and field data. }\end{array}$ \\
\hline $\begin{array}{l}\text { MRC } \\
\text { Hydrogeological map } \\
\text { of LMRB }\end{array}$ & $1: 2,000,000$ & 1998-2011 & MRC & $\begin{array}{l}\text { Used as an indicator for identification of } \\
\text { units. Fairly limited accuracy in Laos. }\end{array}$ \\
\hline $\begin{array}{l}\text { Geological map of } \\
\text { Vientiane area }\end{array}$ & $1: 200,000$ & 1999 & DGVM & $\begin{array}{l}\text { Includes stratigraphy and cross-sections. } \\
\text { Used for assessing national map } \\
\text { accuracy and aquifer units identification. }\end{array}$ \\
\hline $\begin{array}{l}\text { Geolgical and } \\
\text { Mineral resources } \\
\text { map of Lao PDR }\end{array}$ & $1: 1,000,000$ & 2008 & $\begin{array}{l}\text { JICA, MEM } \\
(\mathrm{DGO}, \mathrm{DOM})\end{array}$ & $\begin{array}{l}\text { Improved quality and accuracy. } \\
\text { Integrates local 1:200,000 scale maps } \\
\text { over } 65 \% \text { of Laos. Used as a baseline for } \\
\text { identification of aquifer units. }\end{array}$ \\
\hline $\begin{array}{l}\text { Geological map of } \\
\text { Attapeu }\end{array}$ & $1: 200,000$ & 2008 & $\begin{array}{l}\text { JICA, MEM } \\
(\mathrm{DGO}, \mathrm{DOM})\end{array}$ & $\begin{array}{l}\text { Includes stratigraphy and cross-sections. } \\
\text { Used for assessing national map } \\
\text { accuracy and aquifer units identification. }\end{array}$ \\
\hline
\end{tabular}

Database Development

Hard copies of reports, tables, and maps were scanned and analyzed to extract data and collect it in a consistent format. Several issues, such as the lack of geographic coordinates, unclear locations and borewell identifications, were solved through cross-checks and GIS mapping. The final database gathered 581 entries, sourced from 10 local and regional reports with specified groundwater data (cf. Table 2). It is considered the first attempt at building a comprehensive groundwater well database in Laos. Although limited in number, regional and local assessments were used to gain an insight on aquifer properties, yields, and groundwater flow. 
Table 2. Data sources used in building borehole database. Sources: JICA: Japanese International Cooperation Agency [14-19]; NTPC: Nam Theun Power Company [22]; ACIAR: Australian Centre for International Agricultural Research [20]; DIC: Deseret International Charities [21]; THXP: Theun Hinboun Expansion Project [35].

\begin{tabular}{|c|c|c|c|c|c|c|c|}
\hline Source & Report & Year & Area & Province & No. Entries & Lithologs & Main Lithological Units \\
\hline JICA & $\begin{array}{l}\text { Basic design study for the development } \\
\text { of groundwater in Vientiane Province }\end{array}$ & 1993 & Regional & Vientiane & 35 & yes/no & Alluvium, Sandstone \\
\hline JICA & Drilling completion report & 1994 & Regional & Vientiane & 147 & yes & Alluvium, Sandstone \\
\hline JICA & $\begin{array}{l}\text { Groundwater Development Study for } \\
\text { Champasak and Saravan Provinces }\end{array}$ & 1995 & Regional & Champassak, Saravan & 22 & yes & Sandstone, Basalt \\
\hline JICA & $\begin{array}{c}\text { Groundwater Development Study for } \\
\text { Champasak and Saravan } \\
\text { Provinces-P-II }\end{array}$ & 2000 & Regional & Champassak, Saravan & 147 & yes & Sandstone, Basalt, Schists \\
\hline JICA & $\begin{array}{c}\text { Rural Water Supply and } \\
\text { Sanitation-databook } 3\end{array}$ & 2000 & Local & Bokeo & 6 & yes & Mudstone, Alluvium \\
\hline NTPC & $\begin{array}{l}\text { Bore design_Technical } \\
\text { report-2007-2008 }\end{array}$ & 2008 & Regional & Khammouane & 162 & yes & Sandstone, Limestone \\
\hline ACIAR & $\begin{array}{l}\text { Well completion report-Project CSE } \\
2009 / 004\end{array}$ & 2009 & Local & Champassak & 5 & yes & Sandstone \\
\hline JICA & Drilling completion report & 2012 & Local & $\begin{array}{l}\text { Xekong, Salavan, } \\
\text { Attapeu }\end{array}$ & 5 & yes & Sandstone, Basalt \\
\hline DIC & $\begin{array}{c}\text { Evaluation of Water Well Drilling } \\
\text { Program-Laos }\end{array}$ & 2013 & Local & Vientiane & 11 & no & Clay, Alluvium \\
\hline THXP & $\begin{array}{c}\text { Appraisal of Groundwater Irrigation } \\
\text { Prospects at THXP } \\
\text { Resettlement Villages }\end{array}$ & 2013 & Local & Bolikhamxay & 41 & yes & Sandstone \\
\hline
\end{tabular}




\subsubsection{Groundwater Storage}

Although the uncertainties are important, most published estimates of the groundwater storage of aquifers over large areas are based on assumptions regarding aquifer thickness and porosity [36]. In some cases [31], estimations could be made on several types of aquifers.

Multilayered aquifer systems are present across most of Laos, particularly in the folded mountain ranges. However, aside from some specific mining areas where investigations have been conducted, the subsurface structural geology is usually unknown. As a consequence, only a single shallow and unconfined aquifer has been considered in this study. It should be noted that most borewell drilling in Laos occurs to a depth of a few tens of meters. Thus, it can be assumed that most of groundwater uses and development are targeting shallow aquifers. It can be equally assumed that the mapped surface geology represents these uppermost aquifers.

In unconfined aquifers, the volume of water available can be expressed by the specific yield (Sy, in \%). The specific yield is the volume of water released from an unconfined aquifer per unit of aquifer area and unit of vertical decline of the water table level. It corresponds to the total porosity (n) without the amount of water retained by capillary forces, also referred as specific retention (Sr).

$$
\mathrm{Sy}=\mathrm{n}-\mathrm{Sr}
$$

Data on Sy and other aquifer properties are lacking in Laos. Previous pump tests were performed to assess water supply capacity, rather than for assessing aquifer properties. Without distant observation wells and with limited pump capacity and short duration, the pumping-test results are often only indicative.

As a consequence, Sy values for each aquifer unit were derived from lithological descriptions or directly obtained from global published literature [37-41]. Acknowledging the uncertainties associated with such approaches, both an average and range of possible specific yields were used for mapping, and in some cases corrected, based on knowledge acquired from regional studies.

The storage volume, expressed in millimeters, was obtained by multiplying the saturated thickness of water by the specific yield. Based on reports and available lithologs (cf. Table 2), a saturated thickness of $30 \mathrm{~m}$ was considered representative of the shallow upper part of most aquifers utilized in Laos. A storage value was assigned to each identified aquifer unit to create a map of groundwater storage.

\subsubsection{Aquifer Productivity}

Mapping the groundwater yield at a high level of detail would require specific aquifer properties, such as transmissivity or hydraulic conductivity. As data are very limited in Laos, statistics on borewell yields have been used instead. In developing countries faced with data scarcity issues, borehole yields present the advantage of being far more often reported, and thus, cover a larger range of areas and lithological contexts [31]. However, reported yields are sometimes underestimating the actual aquifer production. For example, in most cases in Laos, reported yields are related to small capacity pumps used for testing drinking supply wells. In the Vientiane Plain, such reported underestimations have been observed for the Alluvial aquifer [14,42]. Still, in most cases, borewell yields offer the only reliable indicator that can be used to estimate aquifer productivity [30].

The yield mapping process included assigning database yields to one of the eight aquifer groups using the borehole logs available. This was based on the assumption that the large majority of borewells are shallow, and intercept a single superficial aquifer. In the rare cases where two aquifer units were encountered, screen numbers, length, and depth have been used to attribute the well to the most representative aquifer. Once classified, the frequency distribution of yields was analyzed when sufficient number of entries were available. When less data was available, the probable yield range was adjusted based on field reports, recorded yields, and previous regional estimates of the MRC. 


\subsubsection{Aquifer Recharge}

Groundwater recharge is a crucial component to assess the potential of groundwater and its sustainability. Here, the recharge has been evaluated over the whole country using recently published data for Laos [33]. In this paper [33], the authors have identified 65 gauging stations across the LMRB, where daily streamflow data was available and not subject to dam regulations. Using the local minimum filtering method, baseflow was calculated for the selected sub-basins. The authors then developed a regional regression model to map the spatial distribution of groundwater recharge rates. The study focused on the whole LMRB, and the resolution of resulting map (1/4-degree) was constrained by the remote sensing products used for the analysis.

In order to obtain a broad estimate of the total annual recharge per aquifer unit, point data extracted from Lacombe et al. (2017) was interpolated using inverse distance weighted technique (IDW) in a GIS-environment. Then, aquifer units previously identified have been used as masks to extract data for each aquifer type and calculate statistics on recharge. One value of minimum, maximum, standard deviation, and average annual recharge have been calculated to describe the variability of recharge for each unit, along with an estimate of the total recharged volume per aquifer unit and rainfall-recharge ratios.

\section{Results}

A total of eight different aquifer units have been identified: (i) Basement aquifers, (ii) Volcanic aquifers, (iii) Schists, (iv) Paleozoic sedimentary, (v) Karsts, (vi) Limestones, (vii) Mesozoic sedimentary, and (viii) Alluvial sediments. These eight categories are mapped in Figure 3, and grouped hereafter within the four major hydrogeological groups previously identified by the MRC in the Lower Mekong River Basin: group 1-Basement and bedrocks, group 2-Late Paleozoic, group 3-Mesozoic and group 4-Alluvial sediments. The following section and Table 3 summarizes the aquifer characteristics for the four groups and eight units. 
Table 3. Comprehensive table of aquifer unit-level groundwater potential indicators.

\begin{tabular}{|c|c|c|c|c|c|c|c|c|c|}
\hline \multirow{2}{*}{ 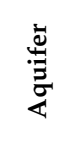 } & \multirow{2}{*}{$\begin{array}{c}\begin{array}{c}\text { Hydro. Groups } \\
\text { (MRC) }\end{array} \\
\text { Aquifer unit }\end{array}$} & \multirow{2}{*}{$\begin{array}{c}\text { Alluvial Sediments } \\
\text { Sands, Gravel, } \\
\text { Clays Mixed }\end{array}$} & \multirow{2}{*}{$\begin{array}{c}\text { Mesozoic } \\
\begin{array}{l}\text { Sandstones } \\
\text { (Mz) }\end{array}\end{array}$} & \multicolumn{3}{|c|}{ Late Paleozoic Sedimentary } & \multicolumn{3}{|c|}{ Basement and Bedrock } \\
\hline & & & & $\begin{array}{c}\text { Sandstones } \\
(\mathrm{Pz})\end{array}$ & Limestones & Karsts & $\begin{array}{l}\text { Early Paleozoic } \\
\text { Schists }\end{array}$ & $\begin{array}{l}\text { Basement Rocks } \\
\text { + Granitoids }\end{array}$ & $\begin{array}{c}\text { Weathered, } \\
\text { Vesicular Basalts }\end{array}$ \\
\hline \multirow{2}{*}{ 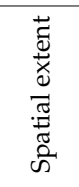 } & Coverage $\left(\mathrm{km}^{2}\right)$ & 8979 & 106,978 & 59,684 & 2690 & 8654 & 19,106 & 12,817 & 7677 \\
\hline & Coverage (\%) & 4.0 & 47.1 & 26.3 & 1.2 & 3.8 & 8.4 & 5.6 & 3.4 \\
\hline \multirow{6}{*}{ 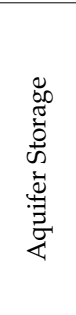 } & $\mathrm{Sy}{ }^{1} \min (\%)$ & 7.75 & 3 & 3 & 0.5 & 2 & 0.25 & 0.25 & 2 \\
\hline & Sy $\max (\%)$ & 18.75 & 15 & 15 & 10 & 15 & 2.55 & 2.55 & 15 \\
\hline & Sy estim (\%) & 13.25 & $8^{*}$ & $4^{*}$ & 5.25 & $12 *$ & 1.4 & 1.4 & $10 *$ \\
\hline & Storage $(\mathrm{mm}) * *$ & 3975 & 2400 & 1200 & 1575 & 3600 & 420 & 420 & 3000 \\
\hline & $\begin{array}{l}\text { Total storage } \\
\left(\mathrm{Mm}^{3}\right)\end{array}$ & 36,864 & 259,818 & 71,913 & 4252 & 32,345 & 8341 & 5629 & 23,058 \\
\hline & $\%$ of Total storage & 8.3 & 58.8 & 16.3 & 1.0 & 7.3 & 1.9 & 1.3 & 5.2 \\
\hline \multirow{2}{*}{ 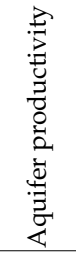 } & $Q$ range $(L / s)$ & $0.3-6$ & $0.1-1.5$ & $0.1-0.8$ & $0.1-1$ & $0-10$ & $0.2-0.5$ & $0-0.5$ & $0.3-3$ \\
\hline & Method & Based on database & $\begin{array}{c}\text { Freq. } \\
\text { distribution }\end{array}$ & $\begin{array}{c}\text { Freq. } \\
\text { distribution }\end{array}$ & $\begin{array}{l}\text { Based on } \\
\text { database }\end{array}$ & MRC & $\begin{array}{l}\text { Based on } \\
\text { database }\end{array}$ & MRC & Based on database \\
\hline \multirow{5}{*}{ 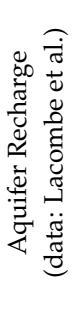 } & Min.-Max. (mm) & 210-1011 & 198-1806 & $206-1631$ & $242-1344$ & $229-1150$ & $191-1658$ & $190-1460$ & $357-1317$ \\
\hline & Average (mm) & 423 & 473 & 494 & 533 & 495 & 592 & 631 & 750 \\
\hline & Standard dev. & 161 & 258 & 269 & 319 & 237 & 321 & 333 & 207 \\
\hline & $\begin{array}{c}\text { Average recharge } \\
\text { vol. }\left(\mathrm{Mm}^{3}\right)\end{array}$ & 38,001 & 505,857 & 294,612 & 14,335 & 42,877 & 113,195 & 80,818 & 57,605 \\
\hline & $\begin{array}{l}\text { Average } \mathbf{R}-\mathbf{R} \\
\text { ratio *** }\end{array}$ & 0.27 & 0.30 & 0.32 & 0.36 & 0.31 & 0.35 & 0.36 & 0.40 \\
\hline
\end{tabular}

${ }^{1}$ Sy: Specific yield, ${ }^{*}$ Values have been corrected based on indirect field observations, otherwise average values were used as estimates; ${ }^{* *}$ considering a saturated thickness of $30 \mathrm{~m}$; *** Recharge to Rainfall ratio. 


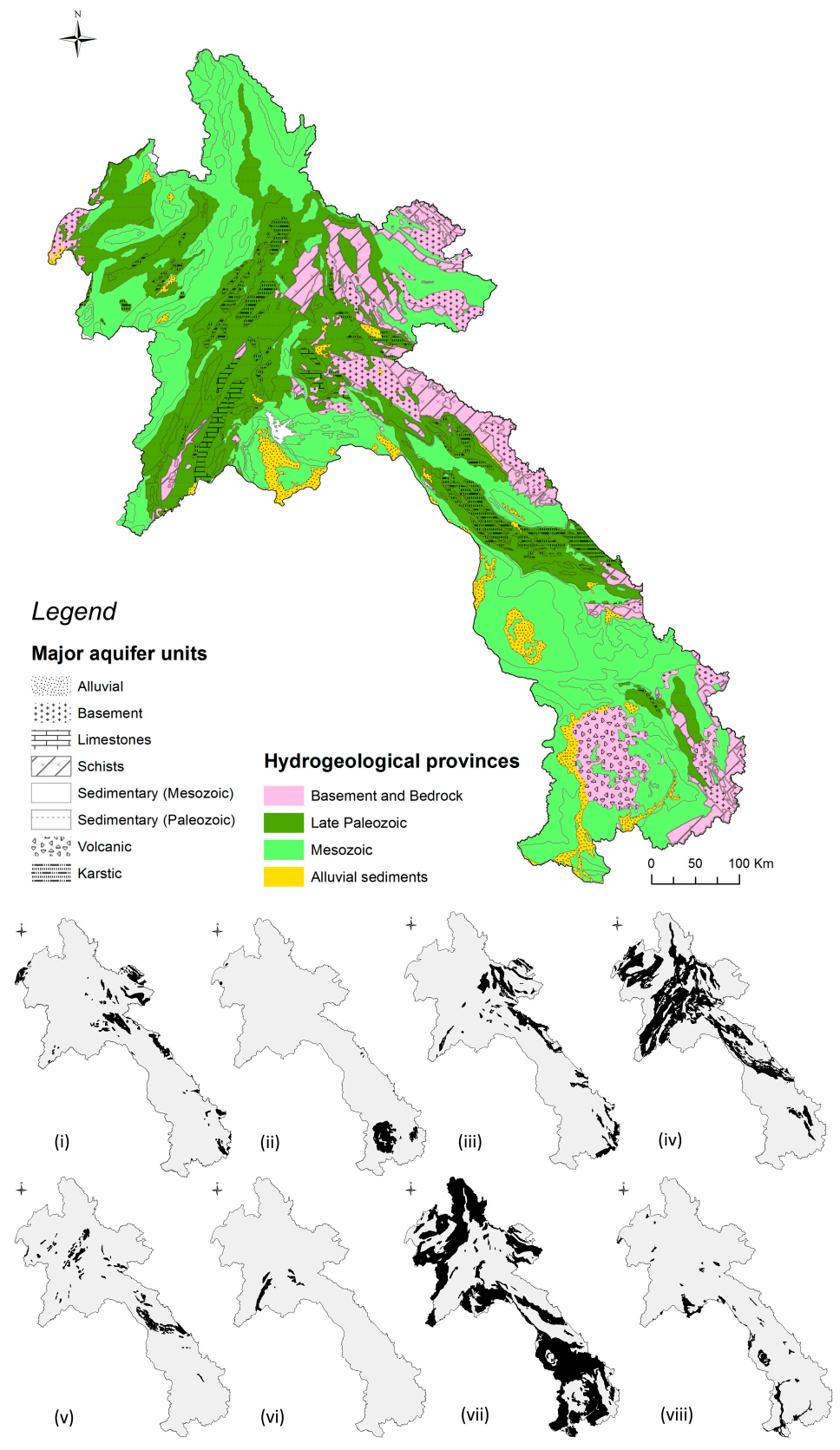

Figure 3. Synthetic map of the four MRC hydrogeological groups (greyscale filling) and the eight identified aquifer units (textures). Sub-maps present the spatial repartition of the 8 aquifer units as (i) Basement aquifers, (ii) Volcanic aquifers, (iii) Schists, (iv) Paleozoic sedimentary, (v) Karsts, (vi) Limestones, (vii) Mesozoic sedimentary, and (viii) Alluvial sediments.

\subsection{Aquifer Characteristics}

\subsubsection{Group 1-Basement and Bedrock}

Three aquifer units have been identified within this group. The metamorphic and igneous rocks (i) are found mainly in the eastern mountain ranges. The basalt lava flows found in the south of the country have been set as a different aquifer category, due to their specific aquifer properties, referred to here as Volcanic aquifers (ii). Third unit is the Early Paleozoic metamorphic rocks, referred as Schists (iii), also considered as a separate category within the Basement rocks group. 
The Basement rocks and Schists are expected to host very limited amounts of groundwater unless intense weathering or fracturing has occurred. Discharge in Basement rock aquifers is expected to be very low $\left(0-0.5 \mathrm{~L} \cdot \mathrm{s}^{-1}\right)$ according to previous estimations at the Mekong scale [13]. Based on field data available in Laos, wells completed in Schists might also achieve a low discharge between 0.2 and $0.5 \mathrm{~L} \cdot \mathrm{s}^{-1}$, and the possibility of dry wells cannot be excluded. The groundwater storage of both formations is very low, estimated at $420 \mathrm{~mm}$, considering a $30 \mathrm{~m}$ aquifer thickness. Covering collectively $14 \%$ of the territory mainly in the mountain ranges along Vietnamese border, these two aquifer units represent only $3 \%$ of the total shallow groundwater storage.

The Volcanic aquifers consist mainly of the basalt lava found in southern Laos forming the Bolaven Plateau. There is very limited data on expected yields from Volcanic aquifers in Laos. Preliminary studies [16] showed that this aquifer can provide yields of up to $3.3 \mathrm{~L} \cdot \mathrm{s}^{-1}$. The aquifer system is expected to be heterogeneous, and reported transmissivities vary from a few tenths up to hundreds of $\mathrm{m}^{2}$.day ${ }^{-1}$ in the most favorable areas [16-18]. Field reports [10] showed that in the lowlands, most villages are tapping the upper weathered and vesicular basalt aquifer, at a thickness varying between 10 and $30 \mathrm{~m}$. Previous estimations of yields in this aquifer by MRC were low $\left(<1.4 \mathrm{~L} \cdot \mathrm{s}^{-1}\right)$, instead, a wider range of 0.3 to $3.0 \mathrm{~L} \cdot \mathrm{s}^{-1}$ is more likely to be expected based on our data review. In terms of groundwater storage, vesicular basalts are found over wide tracts of the lowlands surrounding the Bolaven Plateau [10] with potentially important storage capacity. A best estimate value of Sy $=10 \%$ was considered, assuming that the basalts of Laos are in the upper range compared to available international literature, and in this case, a storage capacity of $3000 \mathrm{~mm}$ over $30 \mathrm{~m}$ has been calculated. The Volcanic aquifers cover only $7600 \mathrm{~km}^{2}$ or $3.4 \%$ of Laos, but account for $5.2 \%$ of its shallow groundwater storage, representing $23 \mathrm{Mm}^{3}$ of water. According to recent estimates [33], the recharge rates for these aquifers are expected to be some of the highest of the country at $750 \mathrm{~mm}$ per annum on average. This is partly due to the geomorphologic features of the Bolaven Plateau leading to some of the highest precipitation in the region.

\subsubsection{Group 2-Late Paleozoic}

Aquifers of this group are composed of thick sedimentary rocks. The Late Paleozoic sedimentary aquifers (iv) are constituted of sandstones and mudstones found in upland areas in central and northern Laos, in SW-NE and SE-NW trending axes. This group also includes the Permian-age extensive Karst aquifers (v) and mid-Paleozoic Limestone aquifers (vi), categorized separately due to their different properties.

The Late Paleozoic sedimentary aquifer units, due to dissection into small blocks during subsequent orogeny, support only local flow [11,13]. As data on yields specific to this aquifer unit are non-existent, the expected yields were obtained based on the frequency distribution of yields for all wells drilled in other sedimentary aquifers (mainly Mesozoic sandstones). Based on these results (cf. hereafter Mesozoic sedimentary aquifer section), and using a conservative approach, a lower range of $0.10-0.8 \mathrm{~L} \cdot \mathrm{s}^{-1}$ was estimated. As these formations are poorly known and studied, the storage was calculated using generic values of Sy and similarly, conservative approaches, have been used. The storage capacity was then estimated using a value of $\mathrm{Sy}=4 \%$. The groundwater storage of this formation was calculated at $1200 \mathrm{~mm}$ for a saturated thickness of $30 \mathrm{~m}$, a value that should only be considered as a broad indicator. Considered as a limited aquifer unit, late Paleozoic sedimentary rocks cover a significant $26.3 \%$ of Laos, while holding only $16.3 \%$ of its shallow groundwater resources. These formations are located over large areas, thus reflecting variable recharge rates ranging from $206 \mathrm{~mm}$ to $1631 \mathrm{~mm}$ per annum.

Limestone aquifers are found outcropping north of Vientiane province, but are generally buried under other formations. There are only a few borewells reported in this aquifer unit. Based on available data, the expected yields range from 0.1 to $1 \mathrm{~L} \cdot \mathrm{s}^{-1}$. Considering an estimated $\mathrm{Sy}=5 \%$, an indicative value of storage of $1575 \mathrm{~mm}$ over $30 \mathrm{~m}$ was estimated. The Limestone aquifer only outcrops over $2690 \mathrm{~km}^{2}$ or $1.2 \%$ of Laos, and represents only $1 \%$ of shallow groundwater storage. 
Extensive Karst systems are found in several parts of Laos. These Karsts are expected to store important amounts of water, but remain essentially unknown, aside from cave system exploration studies $[43,44]$. Karsts are found in various forms, including towering karsts, a famous landmark of the touristic landscape of Laos, and some of the largest caves and underground rivers in Asia [45]. There are no reported yields in this unit, and estimating expected borewell discharge in such heterogeneous aquifers is always challenging. Here, an interval of 0 to $10 \mathrm{~L} \cdot \mathrm{s}^{-1}$ has been used, based on previous MRC estimates. A specific yield for Karsts of $S y=12 \%$ has been used, resulting in a storage capacity of $3600 \mathrm{~mm}$ considering a $30 \mathrm{~m}$ aquifer. This high storage capacity means that Karst systems would store $7.3 \%$ of total shallow groundwater resources, while outcropping in only $3.8 \%$ of the territory.

\subsubsection{Group 3-Mesozoic}

This aquifer group also comprises of thick sedimentary rocks (sandstones, siltstones, etc.) with variable degrees of consolidation. However, these sedimentary sections form a different group from earlier sedimentary rocks, as in this case, they form both deep confined and shallow unconfined aquifers in the LMRB and support regional flow systems [13]. In Laos, these formations outcrop in several locations, including northern and central mountainous provinces. They also extend under most of central and southern lowlands as a continuity of Thailand's Khorat Plateau, and are referred to as the Mesozoic sedimentary (vii) aquifer.

A total of 288 reported yields were used to estimate a range of expected yields, sourced from limited studies available $[16,17,19-22,35]$. Based on the frequency distribution of yields, the interquartile range of yields was $0.3-0.7 \mathrm{~L} \cdot \mathrm{s}^{-1}$. However, the interquartile interval was then corrected. Corrections were based on the assumption than yields reported were representing only a fraction of the aquifer productivity. These corrections did not take into account neither the low production wells often observed but unreported $[9,46]$, nor considered the full potential of the aquifer (due to wells built for cost-effectiveness rather than maximizing productivity). Thus, the interval has been modified closer to the MRC estimations, which was based on a much larger set of information, including the Khorat Plateau in Thailand, bearing similar properties. The expected range of yields for the Mesozoic sandstones aquifer group is then estimated at $0.1-1.5 \mathrm{~L} \cdot \mathrm{s}^{-1}$. Considering a $\mathrm{Sy}=8 \%$, the storage has been estimated at $2400 \mathrm{~mm}$. A major feature of Mesozoic sedimentary aquifers is their extent in Laos. Covering more than $100,000 \mathrm{~km}^{2}$, it represents nearly half of the country $(47 \%)$. Recharge is highly variable over the entire aquifer coverage, ranging from $198 \mathrm{~mm}$ to $1806 \mathrm{~mm}$ per annum. With significant storage capacity and large spatial coverage, this type of aquifer stores an estimated $58 \%$ of the country's shallow groundwater, highlighting its considerable importance.

\subsubsection{Group 4-Alluvial Sediments}

Formed of Neogene and Quaternary deposits, these Alluvial aquifers (viii) are found in lowland areas near Vientiane province, in Savannakhet and along the Mekong river. Although often not mapped, small Alluvial deposits can also be found along rivers in upland areas. Alluvial aquifers in Laos can be considered as homogeneous at wide scale, although strong heterogeneities might exist over short distances, due to variable clay content, as observed in the Vientiane Plain $[14,18,28]$.

Surprisingly, there are very limited numbers of recorded yields for the Alluvial aquifers, despite these being heavily relied upon in areas such as Vientiane Plain or Alluvial intermontane valleys. Investigations for community groundwater supply $[14,18]$ are the main source of data on this aquifer unit. The heterogeneity is reflected by the few transmissivity values available, ranging from as low as 1.7 up to $188 \mathrm{~m}^{2} \cdot$ day $^{-1}$ [14,42]. Reported yields range from $0.1 \mathrm{~L} \cdot \mathrm{s}^{-1}$ up to $5.9 \mathrm{~L} \cdot \mathrm{s}^{-1}$. These values are relatively close to the expected yields mapped by the MRC [11-13] of 1.38 to $8.3 \mathrm{~L} \cdot \mathrm{s}^{-1}$. However, the number of entries is limited ( 93 borewells), and a large number of reported yields are lower than expected. This can be explained by some analysis [14] being mainly focused on small boreholes for hand pumps with pump tests carried out with low capacity submersible pumps, thus not representing the actual aquifer productivity. In comparison, a $20 \mathrm{~cm}$ (8 inch) diameter irrigation borehole drilled 
to maximize productivity in the same Alluvium [42] could sustain pumping rates up to $5 \mathrm{~L} \cdot \mathrm{s}^{-1}$. It is considered that a range of 0.3 to $6 \mathrm{~L} \cdot \mathrm{s}^{-1}$ can be expected from these aquifers in Laos.

An estimate of $S y=13 \%$ has been used. This value is also within the same order as specific yield estimated in the Vientiane Plain [27,42]. Using this value of specific yield, a storage up to $3975 \mathrm{~mm}$ can be expected if considering a $30 \mathrm{~m}$ saturated aquifer thickness. The Alluvium recharge rates, according to recent estimates [33], range between $210 \mathrm{~mm}$ and $1011 \mathrm{~mm}$. These values, lower than for larger sedimentary aquifers, can be explained by the location of the Alluvium in the lowlands, where lesser precipitation occurs. Alluvium deposits represents only $4 \%$ of the territory, but $8 \%$ of total groundwater storage with $3.69 \times 10^{4} \mathrm{Mm}^{3}$.

\subsection{Mapping of Storage, Productivity, and Recharge}

Data collection and review, followed by the integration of both local and regional datasets, allowed the construction of three maps depicting the groundwater storage, the aquifer productivity, and average recharge for each identified aquifer unit. The combination and assessment of these three components provide a useful way to evaluate the groundwater development potential of each unit. The following Figure 4 describes the aquifer property indicators, and Figures 5-7 present the three maps produced.

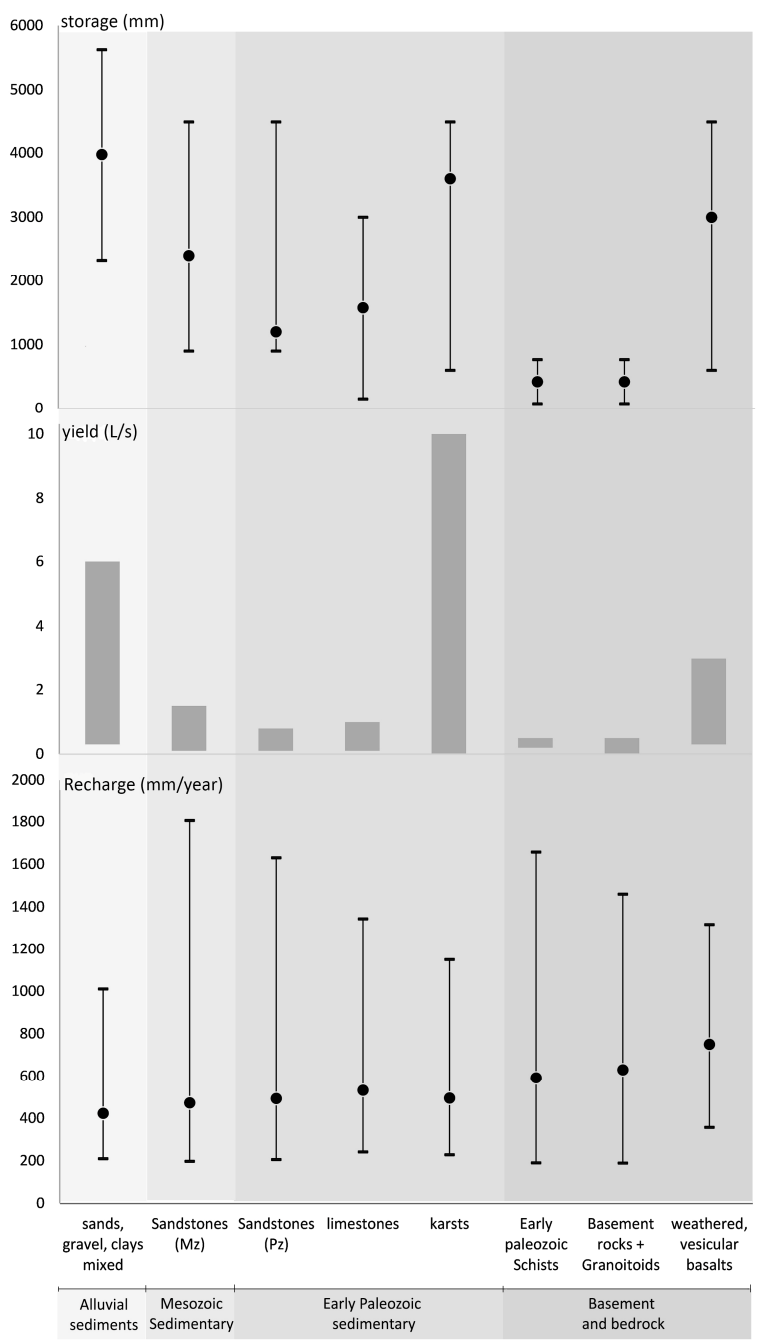

Figure 4. Overview of the hydrogeological indicators in Laos. Storage (min-max and average) is in $\mathrm{mm}$, considering a $30 \mathrm{~m}$ saturated aquifer thickness; borewell yields range in L/s and minimum, maximum and average annual recharge in $\mathrm{mm}$ (recharge data source: [33]). 


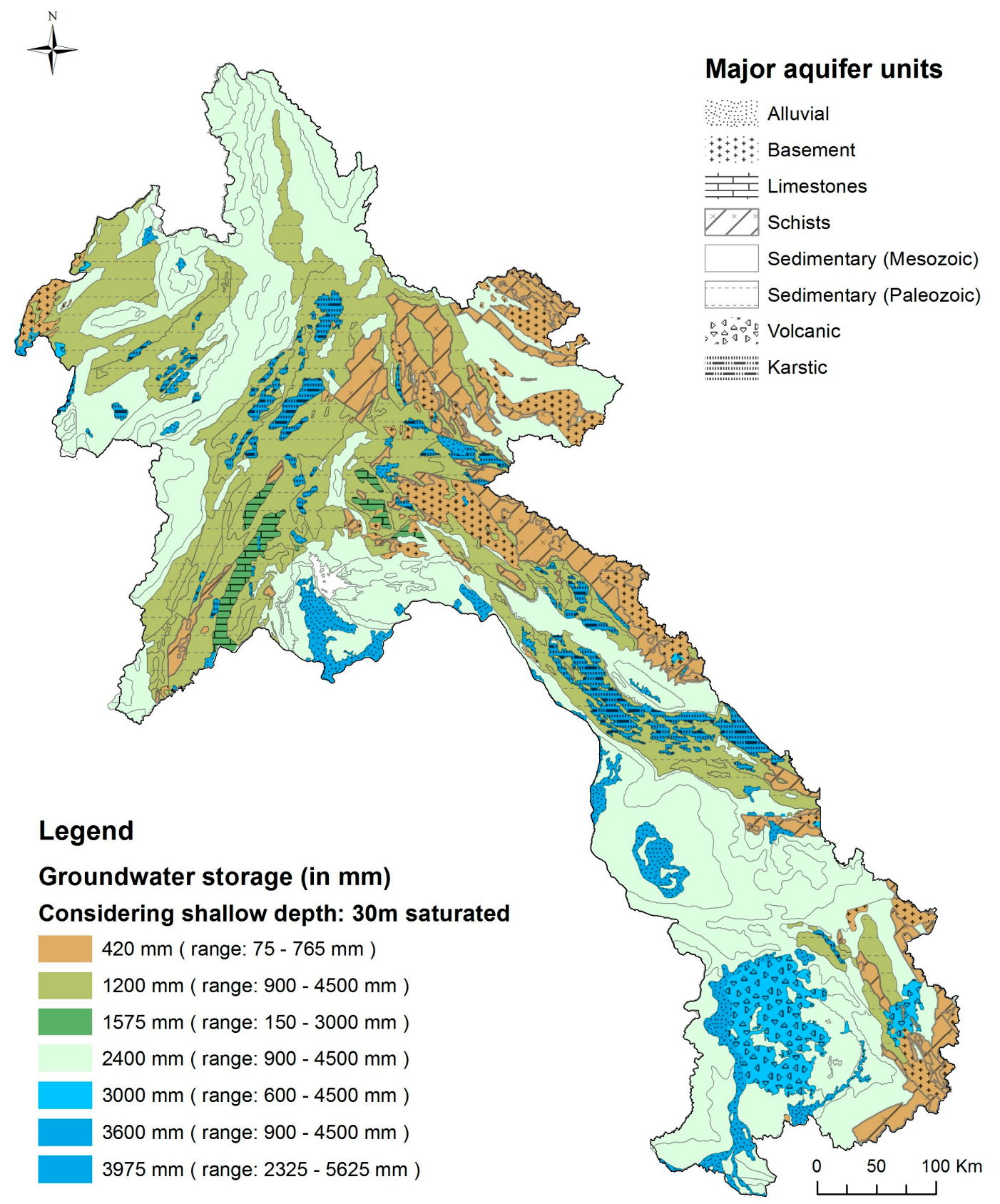

Figure 5. Map of shallow groundwater storage in Laos, considering a $30 \mathrm{~m}$ saturated thickness. 


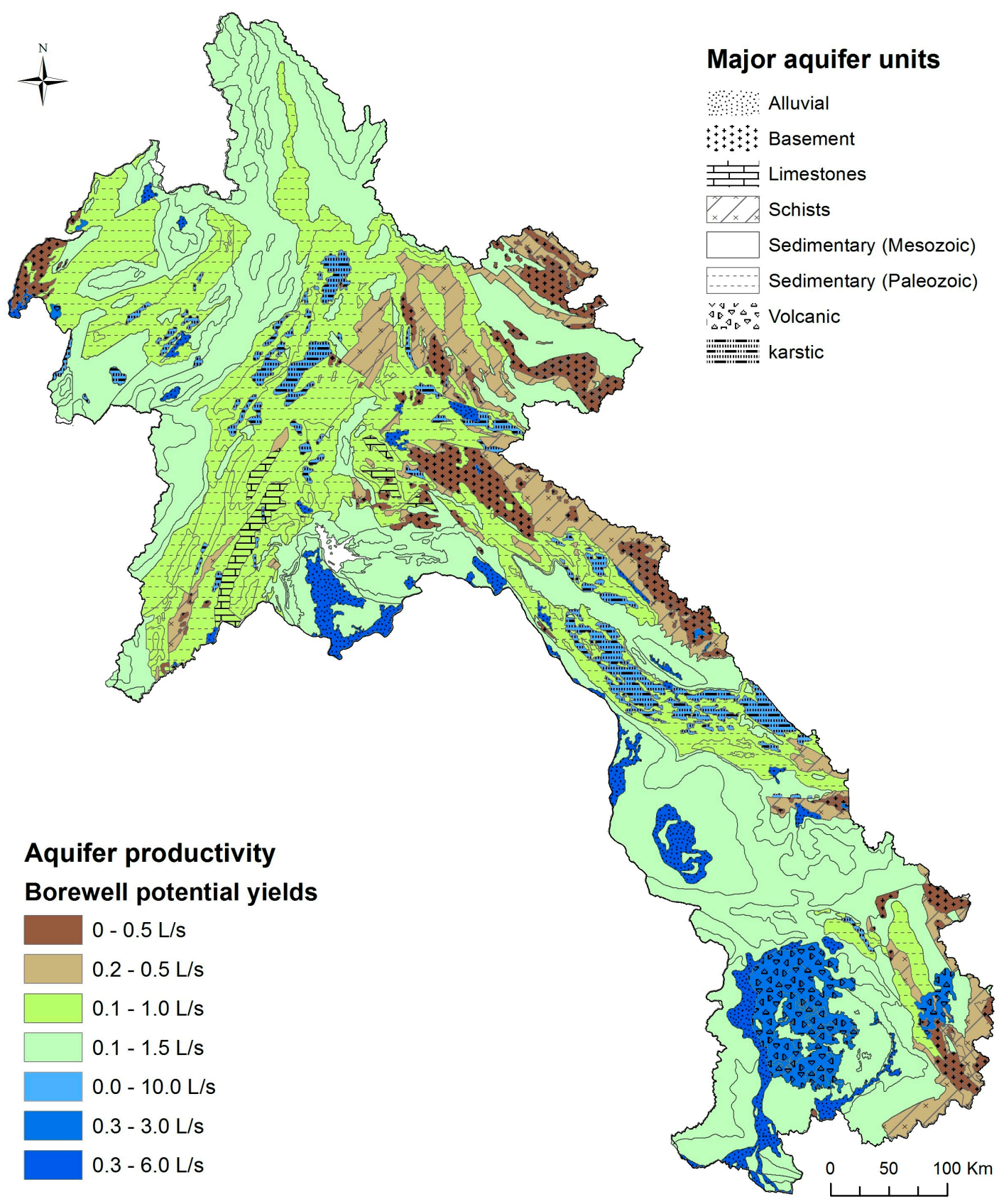

Figure 6. Map of shallow aquifer productivity in Laos. 


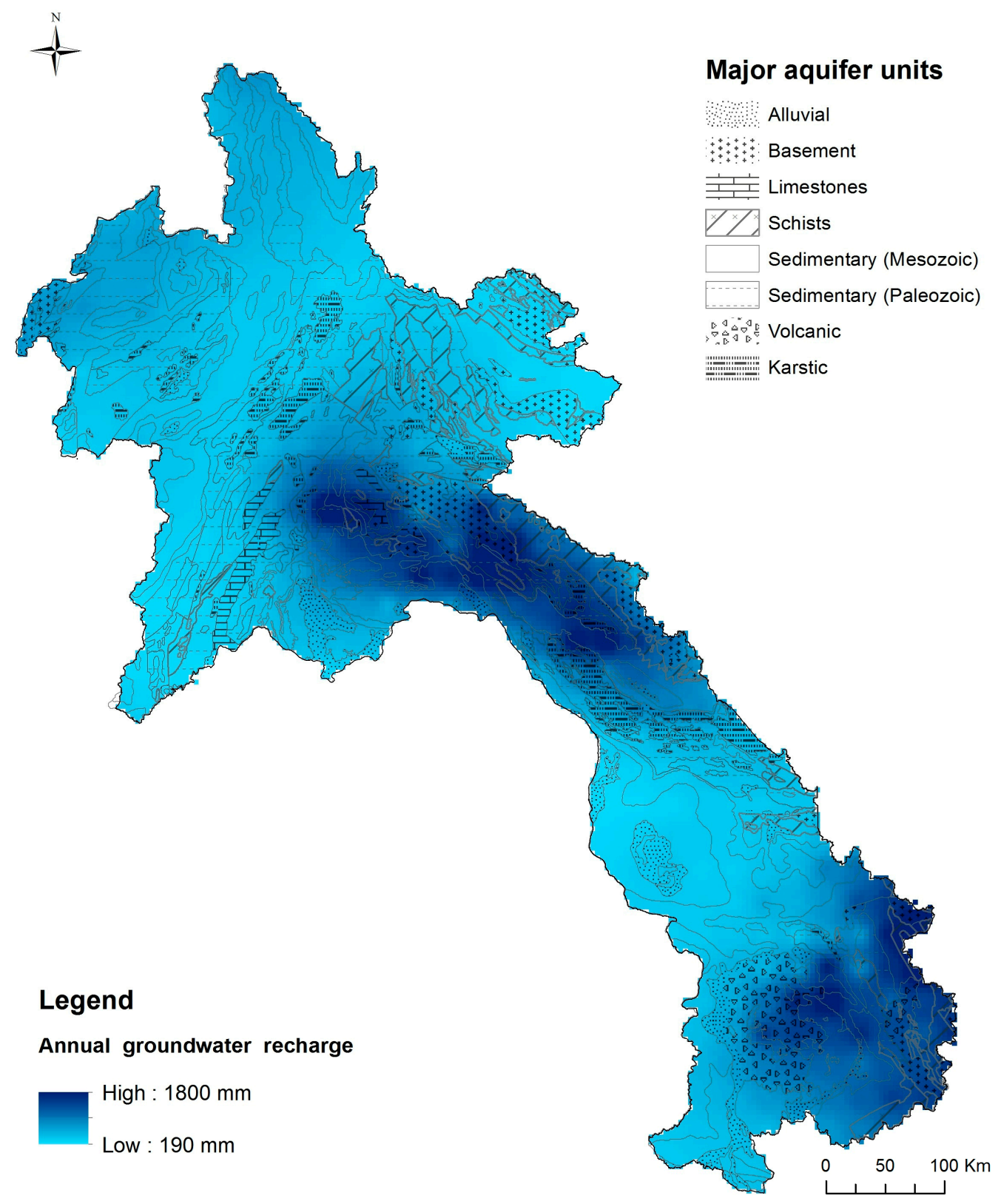

Figure 7. Map of annual groundwater recharge in Laos, estimated based on recent results [33].

\subsection{Groundwater Potential}

Integrating the aggregated aquifer characteristics and spatial extent allows us to make an initial assessment of the groundwater potential for the eight identified major aquifer units. Three main areas can be highlighted as discussed below.

\subsubsection{Areas of Significant Groundwater Importance}

The Mesozoic sandstones and the Alluvial aquifers have been identified as being the most important at the scale of Laos, for different sets of reasons.

The Alluvial aquifers extend over limited areas and limited thickness, however, with both high storage and important yields, it represents the most productive aquifer type in Laos. Groundwater is already largely used in some of Laos Alluvial plain for domestic uses, and marginal cash crop irrigation. In terms of quality, these aquifers present, overall, satisfactory levels of major ions and 
heavy metals, but are often the most prone to contamination from the surface [47]. In central and southern Laos, Alluvial aquifers are sometimes underlain by Mesozoic sandstones, possibly containing salts. Along the Mekong floodplains, arsenic has been found in groundwater in some locations [48]. These elements create constraints to be taken in consideration for groundwater development.

The Mesozoic sandstones are considered of great importance in Laos. This is due to their intrinsic storage properties, their important thickness, up to several hundred meters, regional groundwater flow system support, and their ubiquitous occurrence in the lowlands. These sandstone aquifers represent the main source of water for hundreds of villages across the country. In most cases, yields constrain its use to domestic purposes only. In some villages, pumps have to be regularly switched off to allow groundwater levels to recover in the borewells $[9,46]$. An important note concerning this aquifer group is the possible presence of evaporite deposits at depth [26-28]. In some locations in Vientiane and Champassak provinces, these deposits are known to be exploited for local salt production [42,49]. There is currently no mapping of the depth and extend of the evaporites in this rock formation. These low borewell yields and salt occurrence are major constraints to the groundwater potential of the Mesozoic sedimentary aquifers.

\subsubsection{Areas Probable Groundwater Development Potential}

Aside from areas of limited potential, areas where there are indicators of a possible groundwater potential, but limited knowledge, have been identified. The large Karsts systems found in Laos possibly possess both a high storage and high yield. However, the lack of knowledge on these formations have been highlighted by several authors, along with difficulties in carrying out explorations, due to poor access and unexploded ordinances (UXOs) remaining from the last Indochina war [43,44,50,51]. The Volcanic aquifers found in southern Laos could also host a significant potential for groundwater development. They are already exploited for domestic uses in several villages, and also support local small-scale water bottling companies. However, in several places, the thickness of the basalt is limited to a few tens of meters, underlain mostly by sandstones. Quality issues, notably arsenic of unknown origin, have been reported in areas where boreholes were drilled through both aquifers [10]. Lack of knowledge is an important issue, with only a few studies having investigated the hydrogeology of the area, mainly from a drinking water supply perspective $[16,18]$. With high storage and yield indicators, coupled with high rainfall and recharge from the plateau during the rainy season, these Volcanic aquifers could represent a hydrogeological region of high importance.

\subsubsection{Areas of Limited Groundwater Development Potential}

The Basement rock and Schist aquifers possess low storage and low yield properties, and are thus considered as poor aquifers. The Paleozoic sedimentary aquifers support larger storage, and expected yields are unknown in Laos, however, their location in mostly upland areas with low population density and very limited arable land, overall limited regional groundwater flow, and likely low yields (based on Mekong scale studies [11-13]), are strong constraints to their use as a viable resource. Thus, Paleozoic aquifers are currently considered as representing a limited groundwater development potential. Similarly, Limestone aquifers might store significant amounts of water, however, these formations being either in upland areas or buried under other formations, they do not represent an important groundwater potential, at least as a shallow, easily accessible resource.

At the country scale, Figure 8 shows that important aquifers underlay more than half of the country, and consist of either productive aquifers (e.g., Alluvium) or important aquifer for livelihood function and regional flow support (e.g., Mesozoic sandstones). Additionally, potentially productive aquifers cover another $8.4 \%$ of the territory, while $40 \%$ can be considered as low groundwater potential. 


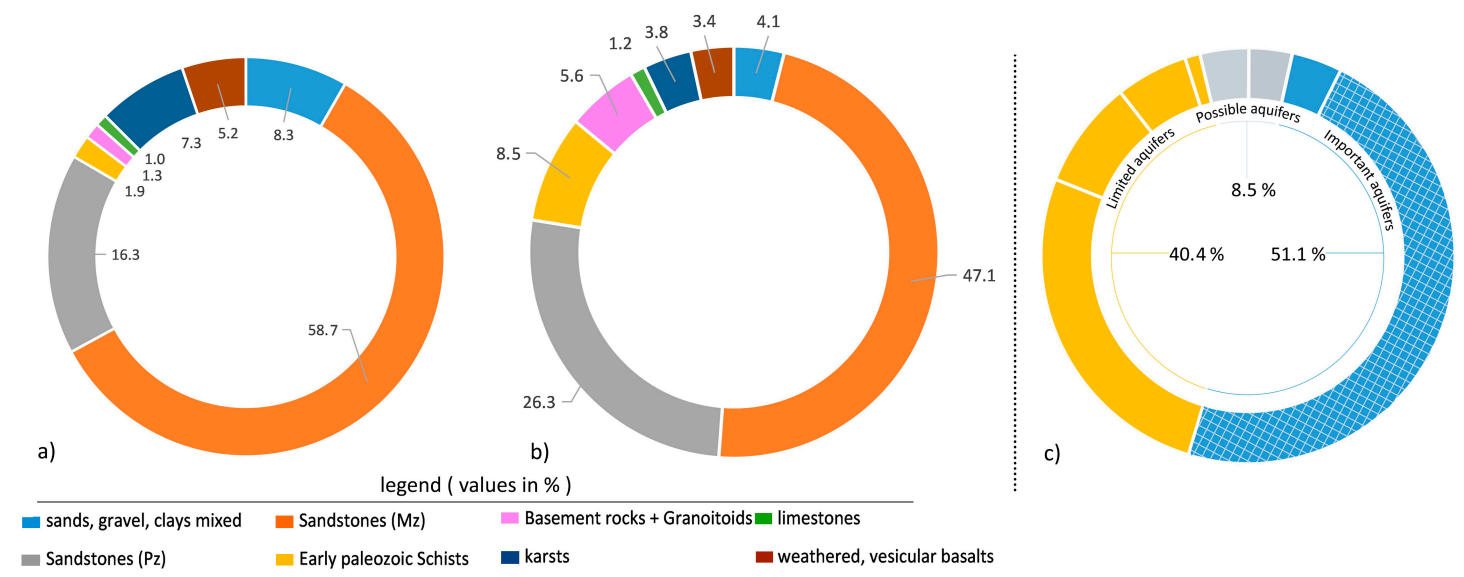

Figure 8. (a) Repartition of total shallow groundwater storage (\%); (b) Relative significance of aquifers in terms of coverage in Laos (\%); (c) Relative significance of limited, possible and important aquifers in terms of coverage of Laos.

\section{Discussion}

The findings from this study show that although often overlooked, Laos hosts aquifer systems of significance over more than $50 \%$ of the country. The Mesozoic sandstone aquifers store large amounts of water, but are of limited productivity, while Alluvial aquifers possess both high storage and productivity, but are limited in their extent. Volcanic and Karst aquifers are also likely to be important aquifer systems, although poorly known. Such generic descriptions are in agreement with previously published literature [11-13]. However, aside from large LMRB scale maps of borewell yield estimates [12,13], there has, to date, been no quantitative indicators for the aquifer units in Laos. Here, the aquifer storage, productivity, and recharge have been calculated using field data or published literature, specifically at the scale of Laos. Furthermore, the spatial accuracy of hydrogeological maps has been significantly improved using the most recent geological maps.

In terms of groundwater development, the Alluvial aquifers and the Mesozoic sandstones are found in lowland areas with the highest population densities with more than 50 and up to 5000 persons per square kilometer (map available in supplementary material, Appendix B).

As of 2014, 28\% of the population of Laos lack access to improved water supply [52]. Groundwater can provide a generally safe and reliable water supply that does not require treatment, although given the shallow nature of the aquifers, specific attention should be given to contamination from human activities (fecal coliforms, nitrate [47]), as well as geogenic source (arsenic [48], uranium [47]). It provides the major source of water for $51 \%$ of villages in Laos (Agricultural Census 2011, map available in Appendix A). High groundwater potential areas provide scope for expansion of safe and reliable water supply to rural communities. In that regard, the Mesozoic sedimentary aquifers present limited potential in terms of productivity and are not likely to support large scale irrigation or industrial development, but are vital for safe domestic water supply over wide areas. The Alluvial aquifers have the capacity to serve the highest priority of domestic water supply provision, but can also support supplementary irrigation during the dry season or dry spells in the monsoon [53]. Currently, less than $0.1 \%$ of irrigated areas use groundwater sources [54]. In areas such as the Vientiane Plain, recent results [33] describe that the area under groundwater irrigation could be, in the future, up to $17.5 \%$, a higher figure than the $10 \%$ considered as irrigated areas today, highlighting the scope for expansion.

Both Karst and Volcanic aquifers might also be considered as important groundwater sources. Present in relatively well populated areas, sometimes away from major river courses and where agricultural land is present, groundwater from these aquifers could provide both safe water supply and small-scale irrigation opportunities. 
As a consequence of population growth and demand-driven changes in agricultural practices, the demand on groundwater resources is likely to rise in future years, calling for the need to better monitor and manage these resources. Developing quantitative indicators and hydrogeological maps allows practitioners to quickly obtain a first-pass estimate of the groundwater development potential of a given area in terms of borewell yields, recharge rates, and available groundwater storage.

Considering the wide scale of the assessment and the assumptions made, these results should be taken as broad estimates, rather than definitive indicators, per se. Data scarcity led to constraints in the method, and reflects the lack of data on aquifer properties. Using generic specific yields as surrogates leads to high uncertainties in the groundwater storage results. Specific yield values ranged up to $13 \%$ between minimal and maximal estimates for a given aquifer unit, leading to variability in estimated aquifer storage capacity. Similarly, limited well yield data presented high variability (up to an order of magnitude) and questionable representativity, related to uncertainties in borehole construction and aquifer heterogeneity. Finally, the large resolution and limitations associated with recharge estimation [33] call for a degree of caution when using it as an approach to determine the upper limits of abstraction.

This paper highlighted several aspects needing further attention, including in-depth assessments of both Alluvial and Mesozoic sedimentary aquifers, improved localized identification of aquifer units and map resolution, and initial investigations on the groundwater resources of the Volcanic and Karst aquifer systems of Laos.

The maps and associated files provide a useful base that can be easily integrated in GIS analysis. Datasets can be integrated in spatially distributed models or weighted overlay models, along with a wide range of biophysical or socioeconomic data (e.g., population, poverty levels, distance to streams etc.) to create new indicators or to refine this analysis.

\section{Conclusions}

Through a systematic identification, mapping and synthesis on aquifer properties of eight aquifer units, and construction of quantitative indicators on storage, productivity, and recharge, this study demonstrates both low and high groundwater potential aquifers are found across Laos. It shows that higher groundwater potential is mostly located in central and southern Laos due to the presence of Mesozoic sandstones and Alluvial aquifers. The Alluvial sediments, the Volcanic aquifers, and probably the Karst systems, present by far, the greater potential in terms of storage and productivity. However, these aquifer systems are either limited in size (e.g., Alluvium) or highly heterogeneous and poorly understood, hindering groundwater development (e.g., Volcanic and Karst aquifers). The Mesozoic sandstones present a lower productivity at small scale, however due to its vast coverage, quantitative importance as a storage unit, and livelihood support function in more densely populated areas, it represents a major aquifer system in Laos that requires further investigation, along with the Karst and Volcanic aquifer systems.

This study provides the first aggregation of data to produce a set of nationwide hydrogeological maps and indicators, providing significant improvements to regional maps available in terms of the spatial resolution, accuracy, and types of aquifer indicators considered. Given the wide scale of the assessment and the assumptions made, high uncertainties call for caution, and to consider these results as broad estimates, rather than definitive indicators per se.

Still, these quantitative indicators and hydrogeological maps allow practitioners to quickly obtain a first-pass estimate of the groundwater development potential of a given area in terms of borewell yields, recharge rates, and available groundwater storage.

The maps and datasets, available in GIS environment, allow for easy integration with other datasets and further analysis. In future, improvement of the accuracy and spatial resolution of these indicators through new hydrogeological studies could significantly widen the scope of this assessment. Hydrogeological studies in priority areas should help improve the understanding of hydrogeological condition in areas where groundwater development is currently occurring (i.e., alluvial plains and 
basalts of southern Laos) and aquifer systems which are important for livelihoods support (Mesozoic sandstones and karstic systems of southern Laos). The role of groundwater in inter-mountain valleys of upland areas should also be investigated in detail to assess its viability in providing safe water access.

With groundwater being increasingly relied upon in Laos, it is hoped that this study provides a timely update on the hydrogeological systems of the country, and will support improved management of the groundwater resources.

Acknowledgments: This work has been supported by the Australian Centre for International Agricultural Research though the project: Enhancing the Resilience and Productivity of Rainfed Dominated Systems in Lao PDR through Sustainable Groundwater Use (Project No. LWR/2010/081) and the CGIAR Research Program on Water, Land and Ecosystems. The authors are thankful for the helpful cooperation provided by the Department of Water Resources and the Department of Irrigation of Lao PDR. The authors are also grateful to Chindavanh Souriyaphack, Somphasith Douangsavanh, Maarten van Eekelen, Corentin Clement, Liliosa Magombedze, Nick Lombardi, Mathieu Chatenet, Rien Dam, Terry Bolger, Shane Wilkes and the two anonymous reviewers of Hydrology journal for their support, advice and fruitful discussions.

Author Contributions: Paul Pavelic, Lisa-Maria Rebelo and Mathieu Viossanges conceived and designed the study. Mathieu Viossanges and Paul Pavelic analyzed the data. Guillaume Lacombe provided analysis on recharge and review the overall analysis, Touleelor Sotoukee provided assistance in databases and GIS operations. Mathieu Viossanges wrote the paper.

Conflicts of Interest: The authors declare no conflict of interest. The founding sponsors had no role in the design of the study; in the collection, analyses, or interpretation of data; in the writing of the manuscript, and in the decision to publish the results. 
Appendix A Map of Locations with Groundwater as Main Water Supply

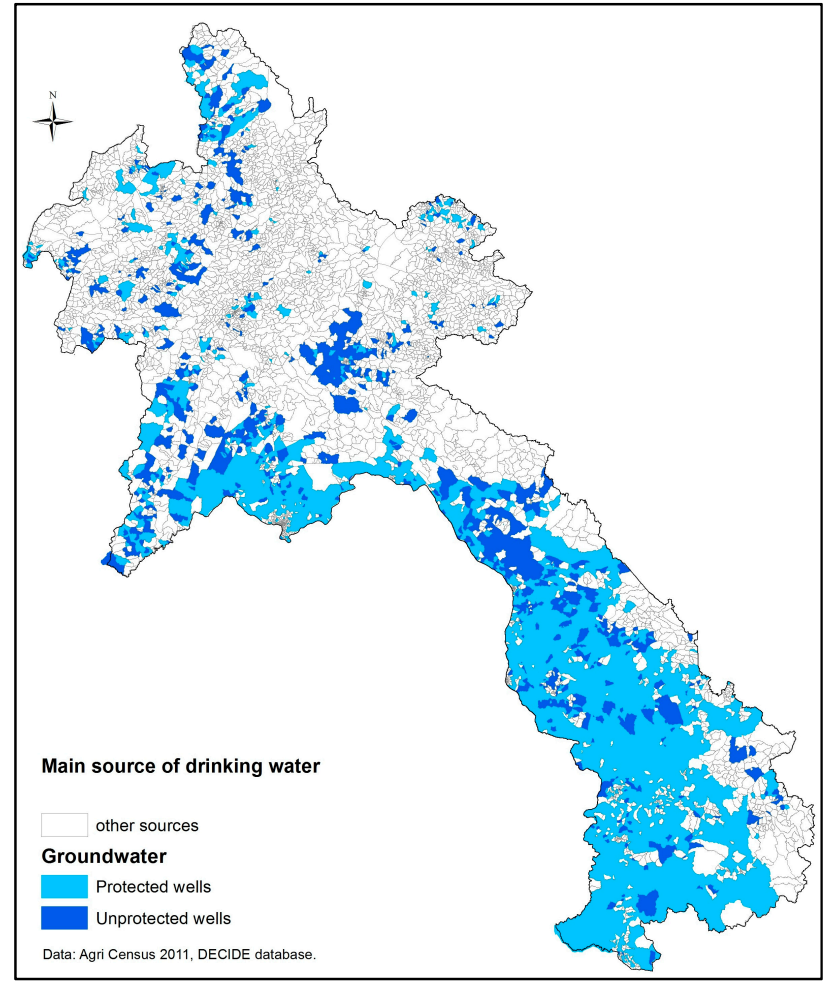

Appendix B Map of Population Density

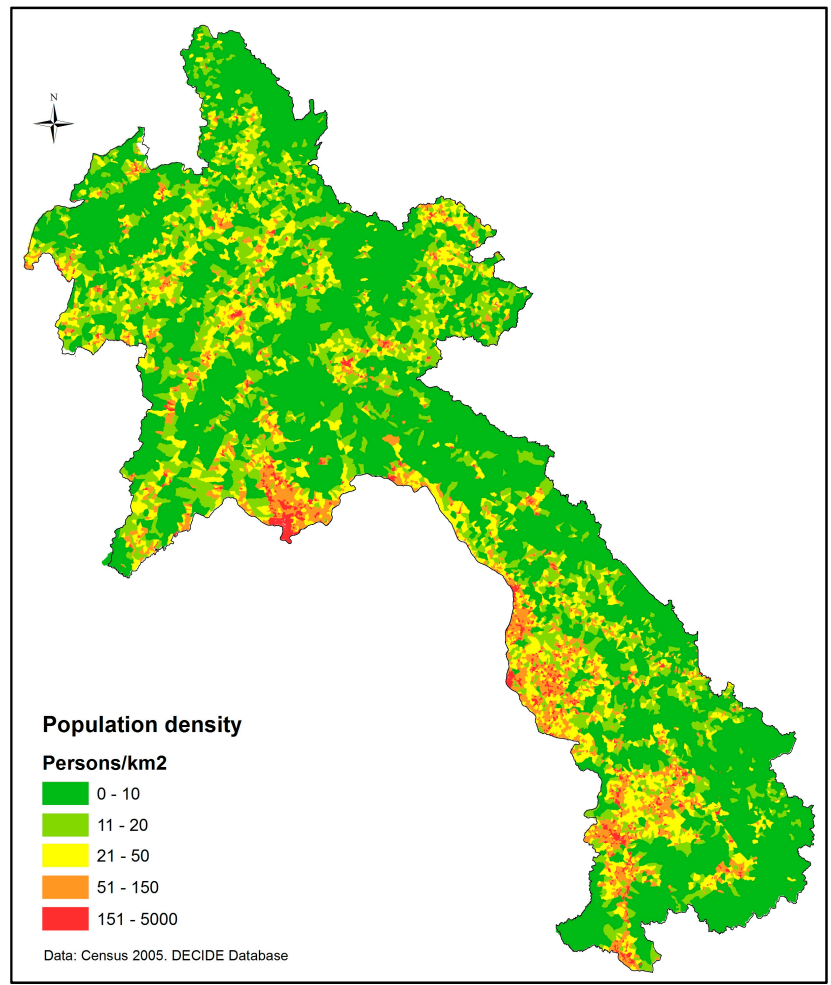




\section{References}

1. UNDP (United Nations Development Program). The Lao Development Journey toward Graduation from LDC Status, Lao PDR. 2012, p. 3. Available online: http:/ / www.la.undp.org/content/lao_pdr/en/home/ library/poverty/ (accessed on 5 January 2017).

2. Lacombe, G.; Douangsavanh, S.; Baker, J.; Hoanh, C.T.; Bartlett, R.; Jeuland, M.; Phongpachith, C. Are hydropower and irrigation development complements or substitutes? The example of the Nam Ngum River in the Mekong Basin. Water Int. 2014, 39, 649-670. [CrossRef]

3. Matthews, N.; Geheb, K. Hydropower Development in the Mekong Region: Political, Socio-Economic and Environmental Perspectives; Routledge: Abingdon-on-Thames, UK, 2014; ISBN 1-317-96413-6.

4. Coulon, C. Recent Progress towards More Effective Groundwater Governance in Lao PDR; Groundwater Solutions Initiative for Policy and Practice (GRIPP) Case Study Series; International Water Management Institute (IWMI): Vientiane, Lao PDR, 2017.

5. GHD Pty Ltd. Lao PDR: Updating the National Water Resources Policy and Strategy; ADB Technical Assistance Consultant's Mid-Term Report; GHD Pty Ltd.: Melbourne, Australia, 2010; Volume 1.

6. Johnston, R.M.; Hoanh, C.T.; Lacombe, G.; Noble, A.; Smakhtin, V.; Suhardiman, D.; Choo, P.S. Rethinking Agriculture in the Greater Mekong Sub-Region: How to Sustainably Meet Food Needs, Enhance Ecosystem Services and Cope with Climate Change; International Water Management Institute: Colombo, Sri Lanka, 2010; p. 26. [CrossRef]

7. Pavelic, P.; Xayviliya, O.; Ongkeo, O. Pathways for effective groundwater governance in the least-developed-country context of the Lao PDR. Water Int. 2014, 39, 469-485. [CrossRef]

8. Vote, C.; Eberbach, P.; Zeleke, K.; Inthavong, T.; Lampayan, R.; Vongthilath, S. The use of groundwater as an alternative water source for agricultural production in southern Lao PDR and the implications for policymakers. A policy dialogue on rice futures: Rice-based farming systems research in the Mekong region. In Proceedings of the Australian Centre for International Agricultural Research, Cambodia, 7-9 May 2014; Volume 103.

9. Vote, C.; Newby, J.; Phouyyavong, K.; Inthavong, T.; Eberbach, P. Trends and perceptions of rural household groundwater use and the implications for smallholder agriculture in rain-fed Southern Laos. Int. J. Water Resour. Dev. 2015, 31, 558-574. [CrossRef]

10. Phommavong, K. Groundwater Flow Systems and Aquifer Storage for Agriculture and Domestic Water Use in Kiet Ngong Village, Pathoumphone District, Champasak Province, Lao PDR. 4th Batch Masters Programme in Environmental Engineering and Management. Master's Thesis, NUOL Faculty of Engineering, National University of Laos, Vientiane, Lao PDR, 2015.

11. Johnson, J.H. Preliminary Appraisal of the Hydrogeology of the Lower Mekong Basin; Interim Mekong River Committee: Vientiane, Lao PDR, 1986; p. 147.

12. Charuratna, A.; Phu, T.H. Hydrogeological Map of Lower Mekong Basin; 1:1,000,000 Scale; Mekong Secretariat; Interim Committee for Coordination of Investigations of the lower Mekong Basin: Bangkok, Thailand, 1992; p. 1.

13. Landon, M. Preliminary Compilation and Review of Current Information on Groundwater Monitoring and Resources in the Lower Mekong River Basin; U.S. Geological Survey Report to the Mekong River Commission; U.S. Geological Survey: Reston, VA, USA, 2011; p. 34.

14. JICA (Japan International Cooperation Agency). Basic Design Study Report on the Project for Groundwater Development in the Vientiane Province in Lao PDR; JICA: Chiyoda, Japan, 1993; p. 199.

15. JICA (Japan International Cooperation Agency). Drilling Completion Report in the Vientiane Province in Lao PDR; JICA: Chiyoda, Japan, 1994; p. 718.

16. JICA (Japan International Cooperation Agency). The Study on Groundwater Development for Champassak and Saravan Provinces in Lao PDR; Final Report; JICA: Chiyoda, Japan, 1995; p. 79.

17. JICA (Japan International Cooperation Agency). The Project for Development of Groundwater in Champassak and Saravan Provinces in Lao PDR; Completion Report. Phase II-Term 2; JICA: Chiyoda, Japan, 2000; p. 331.

18. JICA (Japan International Cooperation Agency). The Study on Rural Water Supply and Sanitation Improvement in North-West Region in Lao PDR; Progress Report; JICA: Chiyoda, Japan, 2000; p. 22.

19. JICA (Japan International Cooperation Agency). The Project for Development of Groundwater in Champasak and Saravan Provinces in Lao PDR; Completion Report. Phase II-Term 3; JICA: Chiyoda, Japan, 2002; p. 195. 
20. ACIAR (Australian Centre for International Agricultural Research). Developing Improved Farming and Marketing Systems in Rainfed Southern Lao PDR; Well Completion Report; Champasak Provincial Health Department: Sukuma, Lao PDR, 2012; p. 35.

21. DIC (Deseret International Charities). Groundwater Evaluation-Somsanga Drug Rehabilitation Center, Vientiane, Lao PDR; Prepared by: Grant Nielsen; DIC: Vientiane, Lao PDR, 2013; p. 24.

22. Lehner, B.; Verdin, K.; Jarvis, A. HydroSHEDS Technical Documentation, Version 1.0; World Wildlife Fund: Washington, DC, USA, 2006; pp. 1-27.

23. NTPC (Nam Theun 2 Power Company). Third Phase Construction of Machine Drilled Boreholes for Domestic Water Supply in New Resettlement Villages, Nakai District, Khammouane Province; Progress reports; NTPC: Khammouane, Lao PDR, 2008.

24. Funk, C.C.; Peterson, P.J.; Landsfeld, M.F.; Pedreros, D.H.; Verdin, J.P.; Rowland, J.D.; Romero, B.E.; Husak, G.J.; Michaelsen, J.C.; Verdin, A.P. A Quasi-Global Precipitation Time Series for Drought Monitoring; Data Series; Earth Resources Observation and Science Center: Reston, VA, USA, 2014; p. 12.

25. BGS (British Geological Survey); DGM (Lao Department of Geology and Mines) and ADB (Asian Development Bank). Lao PDR Geological and Mineral Occurrence Map, Geological History Included in Map; Annells, R.N., Coats, J.S., Eds.; BGS: Swindon, England; DGM: Vientiane, Lao, 1991; p. 1.

26. Zhang, X.; Ma, H.; Ma, Y.; Tang, Q.; Yuan, X. Origin of the late Cretaceous potash-bearing evaporites in the Vientiane Basin of Laos: $\delta 11 B$ Evidence from borates. J. Asian Earth Sci. 2013, 62, 812-818. [CrossRef]

27. Wiszniewski, I.; Lertsirivorakul, R.; Merrick, N.P.; Milne-Home, W.A.; Last, R. Groundwater flow section modelling of salinisation processes in the Champhone catchment, Savannakhet Province, LAO PDR. In Proceedings of the International Conference on Simulation and Modeling, Nakhonpathom, Thailand, 17-20 January 2005.

28. Perttu, N.; Wattanasen, K.; Phommasone, K.; Elming, S.-Å. Characterization of aquifers in the Vientiane Basin, Laos, using Magnetic Resonance Sounding and Vertical Electrical Sounding. J. Appl. Geophys. 2011, 73, 207-220. [CrossRef]

29. ICHS (Inter-African Committee for Hydraulic Studies). Explanatory Notice and Recommended Usage of the Map of Potential Groundwater Resources in Western and Central Africa 1:5,000,000; ICHS, BRGM: Orleans, France, 1886; p. 74.

30. Martin, N.; van de Giesen, N. Spatial Distribution of Groundwater Production and Development Potential in the Volta River basin of Ghana and Burkina Faso. Water Int. 2005, 30, 239-249. [CrossRef]

31. MacDonald, A.M.; Bonsor, H.C.; Dochartaigh, B.É.Ó.; Taylor, R.G. Quantitative maps of groundwater resources in Africa. Environ. Res. Lett. 2012, 7, 024009. [CrossRef]

32. Zektser, I.S.; Lorne, E. Groundwater resources of the world: And their use. In IhP Series on Groundwater; UNESCO: Paris, France, 2004.

33. Lacombe, G.; Douangsavanh, S.; Vongphachanh, S.; Pavelic, P. Regional assessment of groundwater recharge in the lower Mekong basin. Hydrology 2017, 4, 60. [CrossRef]

34. THXP (Theun Hinboun Power Company-Expansion Project) and Hydrogeosci Co. Ltd. An Appraisal of Groundwater Irrigation Prospects at THXP Resettlement Villages; THXP: Vientiane, Lao PDR, 2013; p. 22.

35. JICA (Japan International Cooperation Agency). The Geological Mapping and Mineral Information Service Project for Promotion of Mining Industry in the Lao People's Democratic Republic; Final Report; JICA: Chiyoda, Japan, 2008; Volume 1, p. 70.

36. Famiglietti, J.S. The global groundwater crisis. Nat. Clim. Chang. 2014, 4, 945-948. [CrossRef]

37. Morris, D.A.; Johnson, A.I. Summary of Hydrologic and Physical Properties of Rock and Soil Materials, as Analyzed by the Hydrologic Laboratory of the U.S. Geological Survey, 1948-1960; Water Supply Paper; US Government Publishing Office: Washington, DC, USA, 1967.

38. Freeze, R.A.; Cherry, J.A. Groundwater; Prentice-Hall: Englewood Cliffs, NJ, USA, 1979.

39. Todd, D.K. Groundwater Hydrology, 2nd ed.; John Willey and Sons: Hoboken, NJ, USA, 1980.

40. Heath, R.C. Basic Ground-Water Hydrology; US Geological Survey: Reston, VA, USA, 1983; Volume 222.

41. Driscoll, F.G. Groundwater and Wells, 2nd ed.; Johnson Screens: St Paul, MN, USA, 1986.

42. ACIAR (Australian Centre for International Agricultural Research). Enhancing the Resilience and Productivity of Rainfed Dominated Systems in Lao PDR through Sustainable Groundwater Use; Final Report for ACIAR Project LWR/2010/081; ACIAR: Canberra, Australia, 2016; p. 86. 
43. Mouret, C.; Vacquie, J.F.; Ghommhid, C.; Ostermann, J.M.; Rolin, J.; Steiner, H. Speleological discoveries in caves of Khammouane, 2005 to 2008, Laos. In Proceedings of the 15th International Congress of Speleology, Kerrville, TX, USA, 19-26 July 2009; White, W.B., Ed.; International Union of Speleology: Kerrville, TX, USA, 2009; Volume 1.

44. Dreybrodt, J.; Laumanns, M.; Steiner, H. Ten years of exploration and over $100 \mathrm{~km}$ of caves surveyed in Northern Laos. In Proceedings of the 16th International Congress of Speleology, Brno, Czech Republic, 21-28 July 2013; Volume 2, pp. 68-73.

45. Mouret, C.; Collignon, B.; Vacquié, J.-F. Giant underground rivers in central Laos. In Proceedings of the 12th International Congress of Speleology, La Chaux de Fonds, Switzerland, 10-17 August 1997; Volume 4, pp. 57-60.

46. Vinckevleugel, J. Institutional Arrangements in Local Groundwater Governance: A Case Study of the Groundwater Resource in Phousan Village, in Phonhong District in Vientiane Province, Laos; Master of Water Sciences, Water and Society; Department of Earth and Water and Environment Sciences, University of Montpellier II: Montpellier, France, 2015.

47. Brindha, K.; Pavelic, P.; Sotoukee, T.; Douangsavanh, S.; Elango, L. Geochemical Characteristics and Groundwater Quality in the Vientiane Plain, Laos. Expo. Health 2017, 9, 89-104. [CrossRef]

48. Chanpiwat, P.; Lee, B.-T.; Kim, K.-W.; Sthiannopkao, S. Human health risk assessment for ingestion exposure to groundwater contaminated by naturally occurring mixtures of toxic heavy metals in the Lao PDR. Environ. Monit. Assess. 2014, 186, 4905-4923. [CrossRef] [PubMed]

49. Milne-Home, W.A.; Last, R.; Souk, B.; Lertsirivorakul, R.; Oondara, B. Groundwater Flow, Salinity Processes and Irrigation Development in the Champone District, Lao PDR. In Proceedings of the 2nd Asian Regional Conference, Moama, Australia, 14-17 March 2004; International Commission on Irrigation and Drainage (ICID): Moama, Australia, 2004.

50. Kiernan, K. Distribution and Character of Karst in the Lao PDR. Acta Carsologica 2009, 38. [CrossRef]

51. Ponta, G.M.; Aharon, P. Karst geology and isotope hydrology of the upstream section of Nam Hinboun River, Khammouan Province (Central Laos). Carbonates Evaporites 2014, 29, 127-139. [CrossRef]

52. WHO (World Health Organization). Water and Sanitation Situation, 2014. Available online: http://www. wpro.who.int/laos/areas/water_sanitation/en/ (accessed on 5 February 2017).

53. Clément, C.; Vinckevleugel, J.; Naolee, K.; Valee, L.; Sotoukee, T.; Shivakoti, B.R.; Vongsathiane, K.; Pavelic, P. Community-Managed Groundwater Irrigation on the Vientiane Plain of Lao PDR: Trial Implementation and Results; Working Paper; Water Management Institute (IWMI): Vientiane, Lao PDR, 2017.

54. FAO (Food and Agriculture Organization). AQUASTAT Information System on Water and Agriculture Country Profile of Lao PDR, 2017. Available online: http:/ / www.fao.org/nr/water/aquastat/countries_ regions/LAO/ (accessed on 2 April 2017). 